\title{
Leadership and organizational performance: State of the art and research agenda
}

Chapter · January 2016

CITATIONS

0

3 authors:

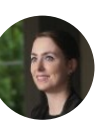

\section{Eva Knies}

Utrecht University

29 PUBLICATIONS 96 CITATIONS

SEE PROFILE

\section{Lars Tummers}

Utrecht University

89 PUBLICATIONS 451 CITATIONS

SEE PROFILE

Christian Bøtcher Jacobsen

Aarhus University

11 PUBLICATIONS 69 CITATIONS

SEE PROFILE 


\title{
Leadership and organizational performance: State of the art and research agenda
}

\author{
Eva Knies (Utrecht University) \\ Christian Bøtcher Jacobsen (Aarhus University) \\ Lars Tummers (Utrecht Rotterdam)
}

In: Routledge Companion to Leadership

(Editors: John Storey, Jean Louis Denis, Jean Hartley, Dave Ulrich \& Paul 't Hart)

To be cited as:

Knies, E.; Jacobsen, C. \& Tummers, L.G. (2016). Leadership and organizational performance: State of the art and research agenda. In: Storey, J., Denis, J.L., Hartley, J. \& 't Hart, P. (Eds.). Routledge Companion to Leadership (pp. 404-418). London: Routledge.

\section{Introduction}

A large portion of the everyday discourse about leadership and leaders takes it for granted that leaders make a big difference in terms of performance. The football managers discussion is one clear example, the wider fascination with business leaders likewise marks this association - and so too the fascination with political leaders. However, the academic literature finds it hard to find reliable evidence for a clear association, because both main concepts (leadership and performance) are broad and difficult to define and because of many confounding variables that make it difficult to demonstrate clear cause and effect. But while some academics have seemingly abandoned the attempt to tackle this difficult but central subject, there are some who seek to trace the relationship. It can be shown that a change of leader does produce some kind of performance outcome. For example, appointments of some leaders and the dismissal of others can trigger dramatic shifts in stock prices. In this chapter we will systematically examine the relationship between leadership and performance, both theoretically (section 2) and empirically (section 3). In section 4 we will use public leadership and performance as illustrative of our analysis. We will conclude with an overview of the current state of the literature and we will outline a research agenda. Overall, we show that empirical studies have mainly found positive relationships between leadership and performance, although effect sizes vary considerably. However, cross-sectional designs with subjective performance measures tend to find relatively strong effects. Therefore, we advocate a systematic approach to studying the leadershipperformance relationship with attention to research designs, and we urge that more panel designs and experimental designs are applied in future studies, because these enable scholars to assess changes over time and getter a much better grasp of causality. 


\section{Background on leadership and performance}

The goal of this section is to provide an overview of the two main concepts central to this chapter: leadership and performance, and to make these more specific so that they can be studied. We will also theoretically explore the link between leadership and performance.

\subsection{Introducing leadership}

Leadership is a powerful term, but it is often weakly conceptualized. In trying to define leadership, Bennis (1959: 259) noted that 'the concept of leadership eludes us or turns up in another form to taunt us again with its slipperiness and complexity. So we have invented an endless proliferation of terms to deal with it ... and still the concept is not sufficiently defined.' In other words, leadership is a 'magic concept'; it is inspiring for scholars and practitioners, but it also vague, meaning everything and nothing at the same time (Pollitt \& Hupe, 2011).

Various authors have tried to make sense of the apparent chaos. Yukl (2013; see for a similar analysis Northouse, 2015) studied the various definitions used by scholars and noted that these have in common that leadership is about an influencing process, more specifically a process whereby intentional influence is exercised over other people to guide, structure, and facilitate activities in groups or organizations. In this chapter, we continue on this line of thought.

In line with this general definition, scholars conceptualized more specific leadership styles, like transformational leadership, transactional leadership, leader-member exchange, empowering leadership, and network leadership. Given space constraints, we will only discuss the background of two core leadership styles that have often been linked to performance (Piccolo \& Colquitt, 2006): transformational and transactional leadership.

\subsection{Transformational and transactional leadership}

Transformational and transactional leadership are broad concepts of which various authors highlight other aspects (Yukl, 2013: 312-313). In his seminal book on political leadership, Burns (1978), for example, focuses mainly on the moral dimension of transformational leadership. According to Burns, transformational leaders offer followers a 'purpose'. They aim to motivate employees by focusing on their moral values, raising their consciousness of moral issues and mobilize their energies to change the current situation. Followers internalize the values - such as eliminating apartheid, equal rights for women and men - proposed, and become intrinsically motivated to perform. In contrast, transactional leaders aim to motivate followers by offering an 'exchange' appealing to their more narrow selfinterest, such as providing jobs or subsidies (Conger \& Kanungo, 1998).

Building upon the work of Burns (1978) and that of Bass and colleagues (Bass, 1985, Bass \& Avolio, 1990, Bass \& Riggio, 2006), transformational and transactional leadership are nowadays considered as higher order constructs composed of several components. For transformational leadership, four components have been identified. First, idealized influence concerns the degree to 
which leaders behave charismatically, so that followers identify with them and consider them to be a role model. Second, inspirational motivation is about communicating a vision which appeals to followers. These first two dimensions are often highly correlated and therefore combined into one 'charisma' factor, often called charismatic leadership (Van Knippenberg \& Sitkin, 2013). Third, transformational leaders provide intellectual stimulation to followers. They challenge them to view problems from a new perspective and, hence, encourage them to generate creative ideas. Fourth, individualized consideration is about giving support to followers, coaching them, and giving them personal attention.

For transactional leadership, three components have been distinguished: contingent reward, management by exception (active) and management by exception (passive). Contingent reward refers to setting goals and rewarding employees when these goals are achieved. In general, management by exception is the degree to which the leader takes action when the behavior of followers is not in line with the expectations. In the 'active' form, leaders actively monitor followers and take corrective actions before the behavior of followers creates serious difficulties. In the 'passive' form, leaders wait until something has gone wrong and take then take corrective action.

\subsection{Introducing performance}

Like leadership, performance is also a broad concept. Performance can manifest itself on different levels and in different forms (Borman \& Motowidlo, 1993; Yammarino et al., 2005). Performance in general can be described as how well a person, a group of persons or an object does a piece of work or activity (Cambridge Dictionary Online, 2015). In organizational research, performance can be conceptualized on various levels of analysis. Here, we distinguish between the organizational level, team level, and individual level.

Organizations can be defined as instruments of purpose (March \& Sutton, 1997). Scholars and practitioners talk about the purposes of an organization and evaluate the success of organizations in reaching these. In essence, they are then talking about the performance of these organizations. However, when discussing organizational performance, Kirby (2005: 36) succinctly stated that 'figuring out who stands tallest is far from straightforward; it depends upon which yardstick you use.' For business firms, profit, sales, and market growth can be used as performance criteria, but also employment in a region. For schools, test scores of students can be used, but also the employment rate (and salary) of former students. Richard et al. (2009) reviewed the literature on organizational performance, and found that across 213 articles published in the top management journals, 207 different measures of performance were used. To provide some clarity, Richard et al. (2009) developed a multidimensional conceptualization of organizational performance, consisting of three specific areas: financial performance (profits, return on assets), product market performance (sales, sales growth, market share) and shareholder return (total shareholder return, economic value added, dividends). This conceptualization is useful, although it is very much focused on private organizations, 
and less suitable for political, administrative or civic organizations (see for instance 't Hart, 2014 and also Section 4 of this chapter).

As with organizational performance, team performance is a broad construct. A team can be defined as two or more persons who interact interdependently and adaptively toward a common goal or objective (Salas et al., 1992). In their meta-analysis on the associations between relationship conflict, task conflict, team performance, and team member satisfaction, De Dreu and Weingart (2003) note that team performance measures in the literature have included product quality, production quality, decision quality, and team effectiveness. Furthermore, some scholars use various team outcomes and team behaviors and combine them into one team performance measure. For instance, Stewart \& Barrick (2000) measured team performance using the following dimensions: knowledge of tasks, quality of work, quantity of work, interpersonal skills, commitment to the team, and overall performance. These were then summed up to tap the construct of team performance. Others used a more differentiated design. For instance, Somech (2006) makes a clear distinction between in-role team performance (the extent to which a team accomplishes its goal) and team innovation (introduction or use of new and useful ideas in a team).

Regarding individual performance, it also becomes clear that various authors define this quite differently. For instance, Welbourne et al. (1996) developed the 'role-based performance scale'. Based on role and identity theory, they identify five key roles when tapping individual performance: job performance (doing things according to the job description, aligned with 'in-role' performance), career performance (obtaining necessary skills to progress), innovator performance (coming up with new ideas and implementing them), team performance (working well with co-workers), and organization performance (going beyond the call of duty in your organization). In a similar vein, Wang et al. (2011) differentiate between task performance (similar to job performance of Welbourne et al.), contextual performance (similar to organization performance), creative performance (similar to innovator performance), and general performance (an overall performance measure).

The goal of this section was to introduce the two concepts central to this chapter: leadership and performance, and to make them more specific so that they can be empirically analyzed. We made a distinction between two leadership styles (transformational and transactional) and three levels of performance (organizational, team, and individual). We fully acknowledge that this is a partial view. There are more ways to analyze the relationship between leadership and performance, using different leadership constructs (for instance Chatterjee \& Hambrick, 2007), or focusing specifically on the role of contextual leadership and performance (Pfeffer \& Salancik, 2003). However, our distinction is in line with the concepts used in recent meta-analyses, as this makes it possible to summarize the empirical evidence that was generated up until now.

\subsection{Connecting leadership and performance}

Before we turn to an overview of the empirical evidence for the link between leadership and performance, we first address the fundamental conceptual debate whether or not leadership 
potentially can have a significant impact on performance. In the literature there are two schools of thought: the 'constraints school' and the 'leadership school' (Pettigrew, 2013; Wasserman et al., 2001). On the one hand, there are scholars who advocate that leaders can only have a very limited impact on performance as a result of contextual constraints, either internal or external to the organization. The study by Lieberson and O'Connor (1972) is a prominent example in this line of thought, which shows that industry and company variables account for more variance in performance than leadership. Related to this, based on attribution theory, some psychologists point out that the impact of leadership on performance is a social construction. According to them, the presence of leadership does not result in high or low performance (other antecedents may be at play), but people interpret it in this way (Weber et al., 2001). This is particularly the case when studying leadership using non-experimental methods, as cause and effect are then hard to separate.

On the other hand, there are others that argue that top managers have sufficient discretion to influence performance (Ireland \& Hitt, 1999; Thomas, 1988). That is, they have strategic choice (Child, 1972). These scholars argue that by shaping the organization's strategy, structure, and culture (Wasserman et al., 2001) through sharing insights, knowledge, and responsibilities (Ireland \& Hitt, 1999), leaders can have a significant impact on performance. An important point that we want to highlight with regard to this discussion is the difficulty to empirically examine the impact of leadership on performance. According to Mackey (2008), as a result of methodological problems, early research has systematically underestimated the impact of leaders on performance. Relevant methodological issues in this respect are: the order in which the independent variables are included in the analyses, the distinction between within and between organization variation (Thomas, 1988), the availability of relevant control variables, and the availability of time series data (Pettigrew, 2013). Recently, the balance between the 'constraints school' and the 'leadership school' seems to have shifted in favor of the latter.

In his book Leadership and Performance Beyond Expectations, Bass (1985) builds a theoretical argument underlying the 'leadership school'. He argues that leaders can be simultaneously transformational and transactional and that both styles of leadership can have beneficial results for performance. Bass notes that in case of transformational leadership, followers feel trust, admiration, and loyalty towards the leader, and therefore are motivated to do more than they are expected to do. Hence, they are performing beyond expectations. In case of transactional leadership there is an exchange process where leaders set goals and rewards in exchange for in-role behavior. Such leadership behavior is important too, but is likely to result in follower compliance rather than in performance 'beyond expectations'. Therefore, based on the work of Bass it may be expected that transformational leadership is more beneficial for performance than transactional leadership.

In the next section we will present an overview of the empirical evidence for the link between leadership and performance. 


\section{Empirical evidence for the link between leadership and performance}

The relationship between leadership and performance has been the subject of many empirical studies. Over the past 30 years, researchers have tried to establish the link between these two concepts. Scholars have used different conceptualizations of the independent variable, such as transactional, transformational, and laissez-faire leadership, and/or have included several related concepts such as trust in leadership, leader-member exchange, and leadership structure. In terms of the dependent variable, we also find a variety of relevant outcomes that have been studied, such as organizational citizenship behavior, employee attitudes, and performance measured using different criteria on different levels of analysis. Also, the relationship between leadership and performance has been studied in different organizational, sectoral, and national contexts. The abundance and conceptual variety of empirical studies into the relationship between leadership and performance raises the question where to start when you want to provide a comprehensive and concise overview of the state of the art? To tackle this problem, we rely on five meta-analyses that have been published on the relationship between leadership and performance: Fuller et al. (1996), DeGroot et al. (2000), Dumdum et al. (2002), Judge and Piccolo (2004), and Wang et al. (2011). The criteria for selecting relevant meta-analyses was that these should include leadership and performance as well as the relationship between the two. According to Wang et al. (2011) the five meta-analyses presented here represent a complete list of relevant studies. As such, these provide an excellent overview of this field of study, not only at present, but also over the past twenty years. Meta-analyses typically provide an understanding of the generalizability of findings of individual studies. The discussion of the successive meta-analyses will show which issues were topical at a particular point in time and give an overview of the most important empirical findings. In doing so, we will highlight how the field has matured over the past decades.

The first meta-analysis dates from 1996. At that time there was a sufficient number of empirical studies to conduct a quantitative review. Fuller et al. used 32 studies with a total of 4,611 participants. Fuller et al. (1996) focused on the effects of charismatic leadership (which is one dimension of transformational leadership) on three outcome variables: satisfaction with the leader, perceived leader effectiveness and performance. Fuller et al. also included several potential moderators: type of performance measure (objective versus subjective), type of research design (multi-source or not), level of the leader, and sample sectoral context. Fuller et al. found positive and significant relationships between charismatic leadership and all three outcome variables. The relationship with the variable 'satisfaction with the leader' was the strongest (mean correlation of .80), followed by perceived leader effectiveness (mean correlation of .79) and overall performance (mean correlation of .45). Moreover, they found significantly stronger correlations for subjective performance measures than for objective ones, indicating that these two reflect different aspects of effectiveness. Also they found that single source studies tend to inflate the relationship between leadership and performance. The level of the leader did not moderate the relationship between leadership and performance. Finally, they showed that the relationship between leadership and performance is not 
generalizable across contexts, for example, military samples provided higher correlations, and student samples show stronger correlations than samples from civilian contexts.

In 2000, DeGroot et al. also conducted a meta-analysis including charismatic leadership as an independent variable. Like Fuller et al. (1996), DeGroot and colleagues included a range of outcome variables: leadership effectiveness, subordinate performance, subordinate satisfaction, subordinate effort and subordinate commitment. The former two were also included in the meta-analysis of Fuller et al. The moderators included in this study were common method variance and level of analysis. DeGroot et al. used 36 samples in their analysis. An important finding is that the relationship between charismatic leadership and subordinate performance is weaker when the latter is measured at the individual level (mean correlation of .31), compared to subordinate performance on the group level (mean correlation of . 49). Furthermore, the study advises researchers to avoid common source bias and apply measures of leadership and performance from independent sources. It must be noted that a majority of the samples used in this meta-analysis are collected in a military context, which provide higher correlations (see Fuller et al., 1996).

In 2002, Dumdum and colleagues performed a meta-analysis including transformational, transactional and laissez-faire leadership as independent variables and performance effectiveness and satisfaction as dependent variables. Organizational type (public versus private) was included as a moderator. This study is an update of a meta-analysis by Lowe et al. (1996), in which they extended their initial time period to 2002. Because the two studies overlap significantly, we report only the results of the later study. The results show that transformational and transactional leadership are both positively and significantly related to the effectiveness/satisfaction criteria. The corrected coefficient are .46 and .20 respectively. Laissez-faire leadership was also significantly related to the effectiveness/satisfaction criteria, but in the opposite direction. The corrected coefficient was -.38. When decomposing the effectiveness/satisfaction criteria, the authors show that satisfaction is more strongly related to transformational and laissez-faire leadership, compared to effectiveness. For transactional leadership they found the opposite: effectiveness is slightly stronger related to this type of leadership compared to satisfaction. Regarding the difference between public and private organizations, Dumdum et al. found mixed results. The relationship between transformational leadership and the effectiveness/satisfaction criteria is stronger in the public than in the private sector. This also holds for laissez-faire leadership, but the difference between the coefficients is much smaller. No data were available for transactional leadership in the private sector.

Another 2002 study by Judge and Piccolo focused on the effects of transformational and transactional leadership on follower leader satisfaction, follower job satisfaction, follower motivation, rated leader effectiveness, leader job performance, and group or organization performance. The latter is of particular interest for this contribution. Like Dumdum et al. (2002), Judge and Piccolo hypothesize that transformational and transactional (contingent reward) leadership show a positive relationship with group or organizational performance. Moreover, they expect that transformational leadership will predict the outcome variables controlling for transactional leadership. As expected, both transformational (mean correlation of .26) and contingent reward leadership (mean correlation of 
.16) have a positive relationship with all dependent variables, including group or organizational performance. The differences between the effects of transformational and contingent reward leadership on group or organizational performance were not significant.

The most recent study by Wang et al. (2011) is based on 117 independent samples. The main independent variable in their meta-analysis is transformational leadership. The dependent variable is performance on three levels of analysis: individual, team, and organization. Wang et al. not only distinguish various levels of analysis, they also include three types of performance: task performance, contextual performance, and creative performance. Overall, they find support for their hypotheses that transformational leadership is positively and significantly related to individual, team and organizational performance. More specifically, they found that the relationship between transformational leadership and individual performance is stronger for contextual performance compared to task performance. They showed that transformational leadership has the strongest relationship with team-level performance (mean correlation of .33) and the weakest relationship with individual-level performance (mean correlation of .25). The mean correlation of the relationship between transformational leadership and organizational-level performance is .27. Additionally, Wang et al. looked at evidence for the augmentation effect. That is, whether or not transformational leadership adds explained variance above and beyond transactional leadership. They found evidence for such an effect for individual-level and team-level performance.

Overall, the five meta-analyses presented above show very consistent results. Without any exception the results show a positive relationship between leadership and performance. More precisely, the first two studies by Fuller et al. (1996) and DeGroot et al. (2000) focus on the effects of one dimension of transformational leadership (i.e. charismatic leadership) on performance outcomes. Both studies find a positive effect. Dumdum et al. (2002) and Judge and Piccolo (2002) analyzed the effect of transformational and transactional leadership on performance outcomes and also found a positive effect. Additionally, Dumdum et al. found a negative effect of laissez-faire leadership on performance effectiveness. Wang et al. (2011) studied the effect of transformational leadership on individual-level, team-level, and organizational-level performance. They found that transformational leadership has a significant relationship with all performance measures, and that the relationship with team-level performance is the strongest (compare DeGroot et al., 2000). Furthermore, Wang et al. found support for the augmentation effect (see also Judge and Piccolo, 2002). However, it should be noticed that the strength of the correlations varies considerably between these five studies. Drawing from the meta-analyses, we can also conclude that the following variables are important moderators in the leadership-performance relationship: type of performance measure (objective versus subjective), type of research design (multi-rater or not), context (public versus private, sector) and level of analysis. Overall, the conclusion that can be drawn from these meta-analyses is that leadership matters for performance. 


\section{Leadership and performance in the public sector}

In this section, we will zoom in on leadership and performance in the public sector as an illustration of our analysis. A focus on the public sector is particularly interesting because it is often said that leaders in the public sector are constrained by rules and regulations (O'Toole \& Meier, 2014). That is, if leaders in the public sector can make a difference for performance, this gives hope for other sectors.

Most leadership studies have focused on private organizations, whereas the role of leadership in public organizations is less investigated and more controversial. Van Wart (2013) recently identified three approaches to public leadership: (1) a generic approach, which highlights the underlying similarities between public and private organizations, (2) a dissimilar approach, which highlights the particular political and societal nature of public leadership, and (3) a convergence approach, which argues that the sectors are becoming more similar over time. These underlying assumptions relate to how leadership can be exerted, the understanding of performance, and the links between leadership and performance.

A central question is what defines public leadership. The publicness tradition has shown that in fact the public-private dichotomy is too simple (Bozeman, 1987). Thus, depending on the ownership status, share of public funding, and level of political involvement, organizations are characterized by various levels of publicness (Bozeman \& Bretschneider, 1994). Publicness is associated with aspects such as complexity (e.g. multiple stakeholders), permeability (high influence from external events), instability (frequent policy changes), and lack of competitive pressure, which can affect the leaders' inclinations and possibilities for exerting leadership (Boyne, 2002). For example, leaders in high publicness organizations are expected to have weaker profit motives (Alchian \& Demsetz, 1972) and face efficiency constraints defined by special interests and competing public goals (Moe, 2012). However, some empirical studies suggest the opposite - that, if at all, publicness is only weakly related with performance, and that leaders may mitigate eventual negative effects (Andrews et al., 2011). Most public management scholars agree that leadership in public organizations to some extent requires distinctive skills and knowledge (Rainey, 2014: 364), and some studies have shown that the impact of leadership depends on context factors (Lim \& Ployhart, 2004; Wofford et al., 2001; Avolio et al., 2009). In terms of theory, however, there is still need for more work on what exactly constitutes public leadership (Vogel \& Masal, 2014: 15).

The classical theories on public leadership view public leaders as being tied up with red tape, vague goals, and organizational constraints (Buchanan, 1976; Warvick, 1975), and expectations towards effective public leadership are diminutive. Administrative leadership is also said to run counter to democratic governance, because accountability risks being obscured, and in terms of performance the common good can become secondary to managerial interest (Terry, 1998). However, there is scant empirical evidence for these expectations. Recent contributions have instead contemplated on how public leaders can become more effective, and for example Tummers \& Knies (2016) suggest that public leaders can support their employees by adhering to four leadership roles: accountability, rule-following, political loyalty, and network governance. This approach deliberately focuses on tasks 
that successful public leaders should attend to, and at the same time acknowledges that more generic, operational and employee-directed leadership roles are also important in public organizations.

Another important question is what defines public performance. Performance is often conceptualized in relation to production and emphasizing aspects such as economy, effectiveness, and efficiency (Walker et al., 2010). However, such measures will often capture only part of what is considered good performance in public organizations. Thus, allocative considerations and equity concerns are typically important prerequisites for public service provision in the first place, and aspects such as citizen and user satisfaction are of interest to for example re-election oriented politicians. Boyne (2003) identified seven dimensions of public performance including quantity and quality of output, efficiency, outcomes, value for money, which resemble the production view, but also equity and satisfaction. Whereas profit is a vital goal in market-based organizations, public organizations may have more difficulty with prioritization of performance dimensions, especially when powerful actors (e.g. politicians, employee organizations, service users) disagree over the prioritization of performance dimensions (Andersen et al., forthcoming). In these instances, an important aspect of public leadership is the willingness and ability to balance performance dimensions. A related challenge is that performance dimensions are not equally measurable (Langbein, 2010), and that goals in public organizations are often ambiguous in the sense that they involve some leeway for interpretation (Chun \& Rainey, 2005). Leaders are therefore likely to be held more accountable for less measurable and more ambiguous goals. This also has implications for research on public leadership. Some argue that objective performance measures are more reliable than subjective ones (O'Toole \& Meier, 2014), whereas others argue that this will lead to a neglect of important performance dimensions (e.g. satisfaction) or performance in certain areas (e.g. quality of administrative work) (e.g. Brewer, 2008). A number of empirical studies have investigated the relationship between transformational and/or transactional leadership and performance in public organizations, and we will now go through some of the most important findings. Wright and Pandey (2009) found that public organizations were less bureaucratic than commonly believed, and that bureaucratic structures had little effect on the prevalence or practice of transformational leadership. This is also backed up by earlier empirical studies, which have shown that public employees regard their leaders as more transformational than their private counterparts (Dumdum et al., 2002). Recently, public management scholars sought to explain how transformational leadership can be particularly relevant in public sector organizations (Paarlberg \& Lavigna, 2010), because the articulation of values, ideologies, and visions speaks to for example public service motivation (Wright et al., 2012).

Several empirical studies have found positive effects of transformational leadership on performance using employee survey based measures of both leadership and performance using crosssectional research designs. A study of 177 Australian administrators reports strong relationships between transformational leadership and performance outcomes, collective efficacy expectancies, and organizational commitment (Muchiri et al., 2012). Chen \& Cheng (2012) also found positive effects of charismatic leadership on subjectively measured performance. Another study reports a mediated effect of transformational leadership on performance through employee satisfaction in a study of 117 
US schools (Griffith, 2004), and an Israeli study of 201 law enforcement agents found a mediating effect of leadership through organizational politics (Vigoda-Gadot, 2007). These studies report strong correlations, but common source bias most likely explains some of this shared variation (Podsakoff \& Organ, 1986; Favero \& Bullock, 2014). To remedy such challenges, Wofford et al. (2001) measured leadership and performance separately and found a positive relationship between employee-rated leadership and manager-rated performance among 157 engineering employees. Another study uses a time series design of more than 1,000,000 US federal employees over seven years and reports that there are remarkably strong intra-organizational patterns in leadership and performance assessments over time, but that improvements in leadership are also associated with improved performance (Oberfield, 2012). Other studies have sought to deal with the common source problem by applying performance measures from administrative sources. A study of 79 Danish upper secondary schools reports that leader and employee ratings of leadership are only weakly correlated (both transformational and transactional (management-by-exception)), and that only employee-rated leadership measures are significantly related with performance measured as school value added (Jacobsen \& Andersen, 2015). On the opposite side, a school study from Singapore finds no effect on objectively measured performance (Koh, Steers, \& Terborg, 2013). These studies do, however, suffer from difficulties with assessing the question of causality.

To address causality better, a few studies have used before-and-after designs, where performance is measured after some inducement to leadership. One study reports the results from 28 public and 22 private Israeli middle-managers that participated in a training program. Looking at changes during the training period, they report effects on satisfaction and effort but not on perceived effectiveness (Parry \& Sinha, 2005). A study of 72 army platoon leaders found that employee-rated transformational and transactional leadership (contingent reward) predicted unit performance, which was measured by external auditors in following mission exercises (Bass et al., 2003). Two studies report findings from experimental studies. An Italian study of 138 nurses reports that nurses, who were randomly assigned to a transformational leadership, were significantly more effective in assembling surgical kits, but that the effect was much greater when the nurses were also randomly assigned to either a self-persuasion treatment or beneficiary contact (Bellé, 2013). Furthermore, the results of the transformational leadership treatment were much stronger for nurses with high levels of public service motivation. A study from the Israeli military reports positive effects on employee performance of a training program, where training was randomly assigned among 41 military platoon leaders (Dvir et al., 2002).

Moving to transactional leadership, this leadership strategy is typically expected to be less useful in public organizations due to constraints on harder HRM tools such as pay, promotion, and benefits. Furthermore, public employees are portrayed as less motivated by extrinsic motives than their private counterparts (Rainey, 1982). Studies have found very mixed results for transactional leadership; some find negative effects (Muchirie et al., 2012; Chen \& Cheng, 2012), whereas others find positive effects (Jacobsen \& Andersen, 2015; Oberfield, 2012). 
Waldman et al. (1990) argue that the best leadership is both transformational and transactional, because transformational behaviors augment the positive effect of contingent reward behaviors resulting in improved subordinate effort and performance. Their study applies a hierarchical regression model based on survey data from 186 navy officers and their 793 employees, and it supports the hypothesis that charismatic and transactional leadership explain unique variance in relation to leader effectiveness and performance. A similar pattern was found in Oberfield (2012), Jacobsen \& Andersen (2015), and Chen \& Chang (2012), and these studies suggest that transformational and transactional leadership are complementary rather than substitutes.

Table 1 sums up the empirical studies reported here in relation to subjects, research designs, leadership strategies, and performance measures in relation to both subjective/objective, level, and type. Also, the main findings are reported. 
Table 1. Overview of published studies on leadership and performance in public organizations

\begin{tabular}{|c|c|c|c|c|c|c|c|c|}
\hline & Study & Subjects & $\mathrm{RD}^{1}$ & $\begin{array}{l}\text { Leader- } \\
\text { ship }^{2}\end{array}$ & Sub/Obj ${ }^{3}$ & Level $^{4}$ & Type $^{5}$ & Findings ${ }^{6}$ \\
\hline 1 & Bellé (2013) & 138 nurses & LE & TFL & 0 & I & OR & $+(++:$ Mod. $)$ \\
\hline 2 & Parry \& Sinha (2005) & 28 public and 22 private middle managers & $\mathrm{BA}$ & TFL & $\mathrm{S}$ & I & SR & 0 (+ for effort) \\
\hline 3 & Vigoda-Gadot (2007) & 201 law enforcement agents & CS & TFL & $\mathrm{S}$ & I & SR & 0 (+: Med.) \\
\hline 4 & Griffith (2004) & 117 schools & CS & TFL & 0 & 0 & OR & $0(+:$ Med $)$ \\
\hline 5 & Dvir, Eden, Avolio \& Shamir (2002) & 41 military platoon leaders and 814 followers & $\mathrm{FE}$ & TFL & 0 & W & OR & $+/ 0$ \\
\hline 6 & Wofford, Whittington \& Goodwin (2001) & 157 engineering employees and 96 managers & HM & TFL & $\mathrm{S}$ & W & OR & + \\
\hline 7 & Bass, Jung, Avolio, \& Berson (2003) & 72 military platoon leaders and 1,340 soldiers & $\mathrm{BA}$ & TFL, PaL & 0 & I & OR & TFL: +, PaL: - \\
\hline 8 & Oberfield (2012) & $1,104,537$ federal employees (five periods) & TS & TFL, TAL & $\mathrm{S}$ & W & SR & TFL \& TAL: + \\
\hline 9 & Jacobsen \& Andersen (2015) & 79 upper secondary schools & CS & TFL, TAL & 0 & 0 & OR & TFL \& TAL: + \\
\hline 10 & Koh, Steers \& Terborg (1995) & 846 school teachers & CS & TFL, TAL & 0 & 0 & OR & 0 \\
\hline 11 & Muchirie, Cooksey \& Walumbwa (2012) & 177 local administrators & CS & $\mathrm{TFL}, \mathrm{SP}$ & $\mathrm{S}$ & $\mathrm{I}, \mathrm{O}$ & SR & TFL +, TAL: - \\
\hline 12 & Waldman, Bass \& Yammarino (1990) & 186 US Navy officers/793 subordinates & $\mathrm{HM}$ & TFL, TAL & $\mathrm{S}$ & $\mathrm{I}, \mathrm{L}$ & $\mathrm{SR} / \mathrm{OR}$ & TFL:,+ TAL: + \\
\hline 13 & Chen \& Cheng (2012) & 1,058 kindergarden teachers & CS & $\mathrm{CL}, \mathrm{TAL}$ & $\mathrm{S}$ & I & SR & $\mathrm{CL}:+, \mathrm{TAL}:-$ \\
\hline
\end{tabular}

${ }^{1}$ RD: Research design, CS: Cross-sectional design, BA: Before and after study, HM: Hierarchical model, LE: Lab experiment, FE: Field experiment

${ }^{2}$ TFL: Transformational leadership, TAL: Transactional leadership, PaL: Passive leadership, CL: Charismatic Leadership, SP: Social Processes leadership

${ }^{3} \mathrm{~S}$ : Subjective, O: Objective

${ }^{4}$ I: Individual, O: Organizational, W: Work group, N: Network, L: Leader, E: Employees

${ }^{5}$ OR: Other-rated, SR: Self-rated

${ }^{6}$ Med: Mediated effects of leadership, Mod.: Moderated leadership effects 


\section{Conclusion}

This chapter has presented and discussed arguments and findings about the importance of leadership for performance in general and has reviewed the research findings on leadership and performance in public organizations in particular. In popular discussions and in some parts of the business management literature, leaders are often portrayed as decisive for organizational success or failure, whereas public administration scholars have traditionally been more skeptical and have underscored that leaders in public organizations face stronger constraints, vaguer goals, and more complex political environments than their private counterparts. This review can only begin to answer the question of whether leadership is effective for performance, because this is indeed a complicated matter to investigate. Not only are both the concept of leadership and performance multi-faceted, but it is also inherently difficult to investigate how leadership affects performance over time.

As shown here, empirical studies have mainly found positive relationships between leadership and performance, although effect sizes vary considerably. Both in generic management studies and in public management studies, cross-sectional designs with subjective performance measures tend to find strong effects, and this reflects a need for stronger methods. The generic management literature often relies on lab experiments with low external validity, and only two public management studies apply before-and-after designs, and two studies use experimental methods, so there is a great need for contributions in this avenue. Thus, despite the growing number of empirical studies, we still lack broad knowledge about the causal effects of leadership. A more systematic approach with attention to research designs would be highly useful, and we urge that more panel designs and experimental designs are applied in future studies, because these enable scholars to assess changes over time and getter a much better grasp of causality. Particularly in relation to socially desirable aspects of leadership, there is risk of endogeneity in relation to performance (Meier \& O'Toole, 2013: 443). We expect that such studies will show more modest effects of leadership on performance, which will also reflect the autoregressive nature of performance, which is affected by a number of internal and external stabilizing factors (O'Toole \& Meier, 2011). Thus, the role of the leader is potentially important, but it should not be exaggerated.

This also leads to the question of which aspects of leadership matter for performance. The leadership literature is immense and offers a vast number of perspectives on leadership strategies and dimensions, and in this review, we have primarily focused on transformational and transactional leadership. These are the most studied leadership concepts in the management literature (Dinh et al., 2012). Public management studies have also applied generic leadership concepts like transformational and transactional leadership, which have also been our focus in this chapter, but we see the beginning of specific public sector leadership theorizing. Future studies could fruitfully integrate these approaches with broader leadership theories, and perhaps even test their relevance for performance. This also touches upon the public-private differences in leadership effects on performance, which we still know very little about. One aspect of this question is which aspects of sector really matter, if at all. We know from other studies that sector can be understood as consisting of for example 
ownership, funding, and regulation, and that these aspects can have very different implications (Bozeman, 1987). Furthermore, it is important to keep the task constant in sector comparisons and at least pay attention to differences relating to for example service delivery versus manufacturing, which could potentially provide very different possibilities for exerting leadership. The meta-studies from the generic management literature have also shown that leadership can function very differently dependent on for example the level of the leader, leader characteristics, and/or follower characteristics. Most existing studies have paid relatively little attention to such moderators, and perhaps this would be an avenue of research for future meta-studies of leadership and performance.

This leads to the performance concept, which still needs to be investigated more broadly in relation to leadership effects. Existing studies have mainly focused on either broad self-assessed measures of performance or on relatively specific measures but also narrower measures related to effectiveness or user satisfaction. However, other aspects of performance such as cost efficiency and equity are also highly relevant performance criteria for many (public) organizations, which are aimed at creating as much value as possible. A systematic approach to investigating leadership effects on different performance dimensions would bring more nuanced knowledge on the actual performance effects of leadership. Such studies could include various leadership styles (transactional, transformational, and others) as well as performance on multiple levels of analysis. Doing so we also urge scholars to consider threats from common source bias seriously and use research designs that measure leadership and performance from independent sources.

The challenge is to systematically assess when, where, and how leadership affects performance. Based on this review we welcome well-designed studies of leadership and performance, because we see a great potential for contributions in this field. 


\section{References}

Alchian, A. A., \& Demsetz, H. (1972). Production, information costs, and economic organization. The American Economic Review, 777-795.

Andersen, L. B., Boesen, A. \& Pedersen, L. H. (2014). Dimensions of performance in public organizations: Clarifying the conceptual space, Paper presented at the PAR 75 anniversary conference, November 16-18 2014, Guangzhou, China.

Andrews, R., Boyne, G. A., \& Walker, R. M. (2011). Dimensions of publicness and organizational performance: A review of the evidence. Journal of Public Administration Research and Theory, 21(suppl 3), i301-i319.

Avolio, B. J., Reichard, R. J., Hannah, S. T., Walumbwa, F. O., \& Chan, A. (2009). A meta-analytic review of leadership impact research: Experimental and quasi-experimental studies. The Leadership Quarterly, 20(5), 764-784.

Bass, B. M. (1985). Leadership and performance beyond expectations. Free Press; Collier Macmillan.

Bass, B. M., \& Avolio, B. J. (1990). Developing transformational leadership: 1992 and beyond. Journal of European Industrial Training, 14(5).

Bass, B. M., \& Riggio, R. E. (2006). Transformational leadership. Psychology Press.

Bass, B. M., Avolio, B. J., Jung, D. I., \& Berson, Y. (2003). Predicting unit performance by assessing transformational and transactional leadership. Journal of Applied Psychology, 88(2), 207.

Bellé, N. (2013). Leading to make a difference: A field experiment on the performance effects of transformational leadership, perceived social impact, and public service motivation. Journal of Public Administration Research and Theory, 24(1): 109-36.

Bennis, W. G. (1959). Leadership theory and administrative behavior: The problem of authority. Administrative Science Quarterly, 259-301.

Borman, W. C., \& Motowidlo, S. M. (1993). Expanding the criterion domain to include elements of contextual performance. Personnel Selection in Organizations, San Francisco: Jossey-Bass, 71.

Boyne, G. (2002). Public and private management: what's the difference?. Journal of Management Studies, 39, 97-122.

Boyne, G. A. (2003). What is public service improvement?. Public Administration, 81(2), 211-227.

Bozeman, B. (1987). All organizations are public.

Bozeman, B., \& Bretschneider, S. (1994). The "publicness puzzle" in organization theory: A test of alternative explanations of differences between public and private organizations. Journal of Public Administration Research and Theory, 4(2), 197-224.

Brewer, G. A. (2008). Employee and Organizational Performance. In: J. Perry \& A. Hondeghem. Motivation in Public Management: The Call of Public Service. Oxford: Oxford University Press, 136-156.

Buchanan, B. (1974). Government Managers, Public Administration Review, 34(4), 339-347.

Burns, J. M. (1978). Leadership. New York: Harper \& Row.

Chatterjee, A., \& Hambrick, D. C. (2007). It's all about me: Narcissistic chief executive officers and their effects on company strategy and performance. Administrative Science Quarterly, 52(3), 351-386.

Chen, Y. \& Cheng, J. (2012). Leadership behavior and job performance of teachers in public and private kindergartens: the perspectives of institutionalization, reason, and feeling. School Effectiveness and School Improvement: An International Journal of Research, Policy and Practice, 23(1), 1-19.

Child, J. (1972). Organizational structure, environment and performance: The role of strategic choice. Sociology, 6(1), 1-22.

Chun, Y. H., \& Rainey, H. G. (2005). Goal ambiguity and organizational performance in US federal agencies. Journal of Public Administration Research and Theory, 15(4), 529-557.

Conger, J. A., \& Kanungo, R. N. (1998). Charismatic leadership in organizations. Sage Publications.

De Dreu, C. K., \& Weingart, L. R. (2003). Task versus relationship conflict, team performance, and team member satisfaction: a meta-analysis. Journal of Applied Psychology, 88(4), 741.

DeGroot, T., Kiker, D. S., \& Cross, T. C. (2000). A meta-analysis to review organizational outcomes related to charismatic leadership. Canadian Journal of Administrative Sciences, 17(4), 356372. 
Dinh, J. E., Lord, R. G., Gardner, W. L., Meuser, J. D., Liden, R. C., \& Hu, J. (2012). Leadership theory and research in the new millennium: Current theoretical trends and changing perspectives, Leadership Quarterly, 25(1), 36-62.

Dumdum, U. R., Lowe, K. B., \& Avolio, B. J. (2002). A meta-analysis of transformational and transactional leadership correlates of effectiveness and satisfaction: An update and extension.

Dvir, T., Eden, D., Avolio, B. J., \& Shamir, B. (2002). Impact of transformational leadership on follower development and performance: A field experiment. Academy of Management Journal, 45(4), 735-744.

Favero, N. \& Bullock, J. B. (2015). How (not) to solve the problem: an evaluation of scholarly responses to common source bias. Journal of Public Administration Research and Theory, 25(1), 285-308.

Fuller, J. B., Patterson, C. E., Hester, K., \& Stringer, D. Y. (1996). A quantitative review of research on charismatic leadership. Psychological Reports, 78(1), 271-287.

Griffith, J. (2004). Relation of principal transformational leadership to school staff job satisfaction, staff turnover, and school performance. Journal of Educational Administration, 42(3), 333-356.

Ireland, R. D., \& Hitt, M. A. (1999). Achieving and maintaining strategic competitiveness in the 21st century: The role of strategic leadership. The Academy of Management Executive, 13(1), 4357.

Jacobsen, C. B., \& Bøgh Andersen, L. (2015). Is leadership in the eye of the beholder? A study of intended and perceived leadership practices and organizational performance. Public Administration Review.

Judge, T. A., \& Piccolo, R. F. (2004). Transformational and transactional leadership: a meta-analytic test of their relative validity. Journal of Applied Psychology, 89(5), 755.

Kirby, J. (2005). Toward a theory of high performance. Harvard Business Review, 83, 30-39.

Koh, W. L., Steers, R. M. \& Terborg, J. M. (1995). The effects of transformational leadership on teacher attitudes and student performance in Singapore. Journal of Organizational Behavior, 16, 319-333.

Langbein, L. (2010). Economics, public service motivation, and pay for performance: complements or substitutes?. International Public Management Journal, 13(1), 9-23.

Lieberson, S., \& O'Connor, J. F. (1972). Leadership and organizational performance: A study of large corporations. American sociological review, 117-130.

Lim, B. C., \& Ployhart, R. E. (2004). Transformational leadership: relations to the five-factor model and team performance in typical and maximum contexts. Journal of Applied Psychology, $89(4), 610$.

Lowe, K. B., Kroeck, K. G., \& Sivasubramaniam, N. (1996). Effectiveness correlates of transformational and transactional leadership: A meta-analytic review of the MLQ literature. The Leadership Quarterly, 7(3), 385-425.

Mackey, A. (2008). The effect of CEOs on firm performance. Strategic Management Journal, 29(12), 1357-1367.

March, J. G., \& Sutton, R. I. (1997). Organizational performance as a dependent variable. Organization Science, 8(6), 698-706.

Meier, K. J., \& O'Toole, L. J. (2013). Subjective organizational performance and measurement error: Common source bias and spurious relationships. Journal of Public Administration Research and Theory, 23(2), 429-456.

Moe, T. M. (2012). Delegation, control, and the study of public bureaucracy. In The Forum, 10(2).

Muchiri, M. K., Cooksey, R. W. \& Walumbwa, R. W. (2012). Transformational and social processes of leadership as predictors of organisational outcomes. Leadership \& Organization Development Journal, 33(7), 662-683.

Northouse, P. G. (2015). Leadership: Theory and Practice. Sage publications.

O'Toole, L. J. \& Meier, K. J. (2014). Public management, context, and performance: in quest of a more general theory. Journal of Public Administration Research and Theory, 25(1), 237-256.

O'Toole, L. J. Jr., \& Meier, K. J. (2011). Public Management: Organizations, Governance, and Performance. New York: Cambridge University Press.

O'Toole, L. J., \& Meier, K. J. (2014). Public management, context, and performance: In quest of a more general theory. Journal of Public Administration Research and Theory.

Oberfield, Z. W. (2012). Public management in time: A longitudinal examination of the full range of leadership theory. Journal of Public Administration Research and Theory, 24(2), 407-29. 
Paarlberg, L. E., \& Lavigna, B. (2010). Transformational leadership and public service motivation: driving individual and organizational performance. Public Administration Review, 70(5), 71018.

Parry, K. W., \& Sinha, P. N. (2005). Researching the trainability of transformational organizational leadership. Human Resource Development International, 8(2), 165-183.

Pettigrew, A. (2013). Can leaders make a difference to organisational performance?. Presentation at the British Academy, 18 April.

Pfeffer, J., \& Salancik, G. R. (2003). The external control of organizations: A resource dependence perspective. Stanford University Press.

Piccolo, R. F., \& Colquitt, J. A. (2006). Transformational leadership and job behaviors: The mediating role of core job characteristics. Academy of Management Journal, 49(2), 327-340.

Podsakoff, P. \& Organ, D. (1986). Self-reports in organizational research: problems and prospects. Journal of Management 12, 531-544.

Pollitt, C., \& Hupe, P. (2011). Talking about government: The role of magic concepts. Public Management Review, 13(5), 641-658.

Rainey, H. G. (1982). Reward preferences among public and private managers: In search of the service ethic. The American Review of Public Administration, 16(4), 288-302.

Rainey, H. G. (2014). Understanding and Managing Public Organizations. John Wiley \& Sons.

Richard, P. J., Devinney, T. M., Yip, G. S., \& Johnson, G. (2009). Measuring organizational performance: Towards methodological best practice. Journal of Management.

Salas, E., Dickinson, T. L., Converse, S. A., \& Tannenbaum, S. I. (1992). Toward an understanding of team performance and training. In R. W. Swezey \& E. Salas (Eds.), Teams: Their training and performance (pp. 3-29). Norwood, NJ: Ablex..

Somech, A. (2006). The effects of leadership style and team process on performance and innovation in functionally heterogeneous teams. Journal of Management, 32(1), 132-157.

Stewart, G. L., \& Barrick, M. R. (2000). Team structure and performance: Assessing the mediating role of intrateam process and the moderating role of task type. Academy of Management Journal, 43(2), 135-148.

't Hart, P. (2014). Understanding Public Leadership. Palgrave MacMillan.

Terry, L. D. (1998). Administrative leadership, neo-managerialism, and the public management movement. Public Administration Review, 194-200.

Thomas, A. B. (1988). Does leadership make a difference to organizational performance?. Administrative Science Quarterly, 388-400.

Tummers, L., \& Knies, E. (2016). Measuring public leadership: Developing scales for four key public leadership roles. Public Administration, 94(2):433-451.

Van Knippenberg, D., \& Sitkin, S. B. (2013). A critical assessment of charismatic: Transformational leadership research: Back to the drawing board? The Academy of Management Annals, 7(1), $1-60$.

Van Wart, M. (2013). Administrative leadership theory: A reassessment after 10 years. Public Administration 91(3): 521-43.

Vigoda-Gadot, E. (2007). Leadership style, organizational politics, and employees' performance: An empirical examination of two competing models. Personnel Review, 36(5), 661-683.

Vogel, R., \& Masal, D. (2014). Public Leadership: A review of the literature and framework for future research. Public Management Review, 1-25.

Waldman, D. A., Bass, B. M., \& Yammarino, F. J. (1990). Adding to Contingent-Reward Behavior. The Augmenting Effect of Charismatic Leadership. Group \& Organization Management, 15(4), 381394.

Walker, R. M., Boyne, G. A., \& Brewer, G. A. (Eds.). (2010). Public management and performance: Research directions. Cambridge University Press.

Wang, G., Oh, I. S., Courtright, S. H., \& Colbert, A. E. (2011). Transformational leadership and performance across criteria and levels: A meta-analytic review of 25 years of research. Group \& Organization Management, 36(2), 223-270.

Warvick, D. P. (1975). A Theory of Public Administration. Thousand Oaks, California: Sage.

Wasserman, N., Nohria, N., \& Anand, B. N. (2001). When does leadership matter? The contingent opportunities view of CEO leadership. Harvard Working Paper no. 02-04.

Weber, R., Camerer, C., Rottenstreich, Y., \& Knez, M. (2001). The illusion of leadership: Misattribution of cause in coordination games. Organization Science, 12(5), 582-598. 
Welbourne, T. M., Johnson, D. E., \& Erez, A. (1998). The role-based performance scale: Validity analysis of a theory-based measure. Academy of Management Journal, 41(5), 540-555.

Wofford, J. C., Whittington, J. L., \& Goodwin, V. L. (2001). Follower motive patterns as situational moderators for transformational leadership effectiveness. Journal of Managerial Issues, 196211.

Wright, B. E. \& Pandey, S. K. (2009). Transformational leadership in the public sector: does structure matter. Journal of Public Administration Research and Theory, 20(1), 75-89.

Wright, B. E., Moynihan, D. P., \& Pandey, S. K. (2012). Pulling the levers: Transformational leadership, public service motivation, and mission valence. Public Administration Review, 72(2), 206-215.

Yammarino, F. J., Dionne, S. D., Chun, J. U., \& Dansereau, F. (2005). Leadership and levels of analysis: A state-of-the-science review. The Leadership Quarterly, 16(6), 879-919.

Yukl, G. (2013). Leading in organizations. Pearson: Upple Saddle River. 